\title{
Technology of Soviet Myth Creation about Famine as a Result of Crop Failure IN UKRAINE OF THE 1932-1933S
}

\begin{abstract}
According to the Ptoukha Institute for Demography and Social Studies of the National Academy of Sciences of Ukraine, over 3, 9 million people died during the famine of the 1932-1933s However, it's impossible to define the exact number of the dead due to liquidation of the 1937 census data by the soviet authorities who deliberately aimed at violating complete record of the deaths and stated in the documentation other death reasons instead of the ones caused by the famine. To disguise this criminal offence the soviet government directed all its efforts to creation of a myth pointing to that year crop failure as the reason of famine.

Purpose. The aim of the following article is to reveal practical techniques of alternative reality creation in the soviet society based on the example of the 1932-1933s famine's mythologization in Ukraine.

Materials and methods. Analyses and generalization of scientific archive sources and international documents, overview of soviet mass media related to the topic have been performed.

Research results. The soviet myth creation technology applied to the famine happening in Ukraine of 1932-1933 as a result of crop failure shows a wide spectrum of alternative reality creation means (mythologization), which was exploited by the whole history of the soviet government: liquidation of documents and evidence, intimidation and physical extermination of witnesses, blockage of access to sources of reliable information, formation of alternative "truth" and its expansion in mass media.

Results. The purpose of creation and expansion of the famine myth based on the belief about crop failure in Ukraine of the 19362-1933s was to form and infix "ideologically correct" interpretation of history in the mass consciousness. It was
\end{abstract}


supposed to disguise reasons of the famine, which was artificially organized by the soviet government in Ukraine, aiming at liquidation of Ukrainian rural population, resisting collectivization, i.e. dissimulating of criminal offences and masking them under ecological myth.

KEYWORDS: famine, mythologization, soviet mass media, collectivization, repressions, peasant protests, parallel reality

\section{Introduction: Reasons of Famine Arrangement BY BOLSHEVIK REgIME IN UKRAINE}

Holodomor (from Ukrainian "holod" - famine, "mor" - mass deaths) is a term defining famine artificially created by the soviet regime of the Soviet Union in 1932-1933. Actually, during the whole period of the USSR existence this topic was under a complete ban - people who had lived through this tragedy never dared to speak publicly about it.

According to Semen Stariv, Holodomor was "execution through famine" [Dolot 1985; Stariv 2006] for extremely insubordinate (if compare with other nations) resistance to collectivization. In the year with decent natural crops in obedience to orders from Moscow the overstated norms of grain were withdrawn from the peasants during grain purchase campaign. Not only were new crop grains brought out, but also sowing grain; not only belonging to collective farms, but also from private peasant farms. Hungarian writer Mate Zalka's diary, who visited Ukraine in summer of 1932, contains the following record under the date of 11-13 June: "Despite normal crops, Ukraine is doomed to famine... It's a tragedy. More and more often I'm driving heavy thoughts out - what is going to happen? Ukraine and it is starving!" [Maestro 2010].

For Moscovia, the Russian Empire, the USSR and now for the Russian Federation, during the whole history Ukraine has always been important due to its geopolitical factors. In the 20-30s of the XXth century active national elite, national conscious and economically independent Ukrainian peasantry was perceived by Moscow as a peculiar threat to the USSR existence, especially after confident attempts to build its own statehood in the 1917 - 1920s. Close neighborhood to the Second Rzeczpospolita (Poland) also afflicted Moscow as 
unlike Ukraine, the neighboring state managed to renovate its independence. His views on this situation Stalin outlined in a letter to L. Kaganovich on August the $11^{\text {th }}, 1932$.:

"Ukraine is the most important thing now. The situation there is extremely bad... If we don't get down to the situation improvements in Ukraine, we can lose Ukraine. You should keep in mind that Pilsudsky is always alert and his agents in Ukraine are much stronger than Redens and Kosior both think. Keep also in mind that in Ukrainian Communist Party (500 thousand members, ha-ha) there are many (yes, not few!) rotten elements, conscious and not conscious petliurivtsi (S. Petliura followers), finally, - direct agents of Pilsudsky. As soon as the situation gets worse, these elements won't lose their chance to start the front" [Stalin i Kaganovich: perepiska... 2001, 273-274].

Besides, industrialization needs demanded considerable costs which, in particular, could be obtained through selling out Ukrainian grain abroad. Ann Applebaum gives the following figures: in 1932 the USSR exported 1, 73 million tons of grain, over 3500 tons of butter, 586 tons of ham. However, in 1933 the export figures grew: 5433 tons of butter and 1037 tons of ham. In times of Holodomor culmination meat and fish tinned products, eggs, chicken meat, fruit and vegetables were actively exported [Holitsyna 2017].

Although soviet government actions also caused hot dissatisfaction in other regions of the USSR, Ukraine resisted collectivization most [Chart 1, Chart 2].

In spring, the 1930 peasant protests and rebellions in Ukraine became massive - peasants began to leave collective farms, taking their property back, willfully freed arrested fellow villagers. Armed revolts took place under the mottos of national and social liberation. Over 4 thousand revolts took place in Ukraine during 1930, about 1,2 million peasants participated in them [Holodomor: henotsyd... 2008, 11; Tylishchak 2016].

The outbreaks didn't stop. While in 1930 the rebellions were of national-social nature, starting from 1932 they were more like rebellions of the hungry. According to Volodimir Tilischak [Tylishchak 2016] within first 7 months in 1932 over 900 mass revolts were on the list in the USSR, which was approximately $57 \%$ of all antisocial revolts in the USSR of that period. 
Chart 1

Anti-Soviet Fight in the USSR in 1930

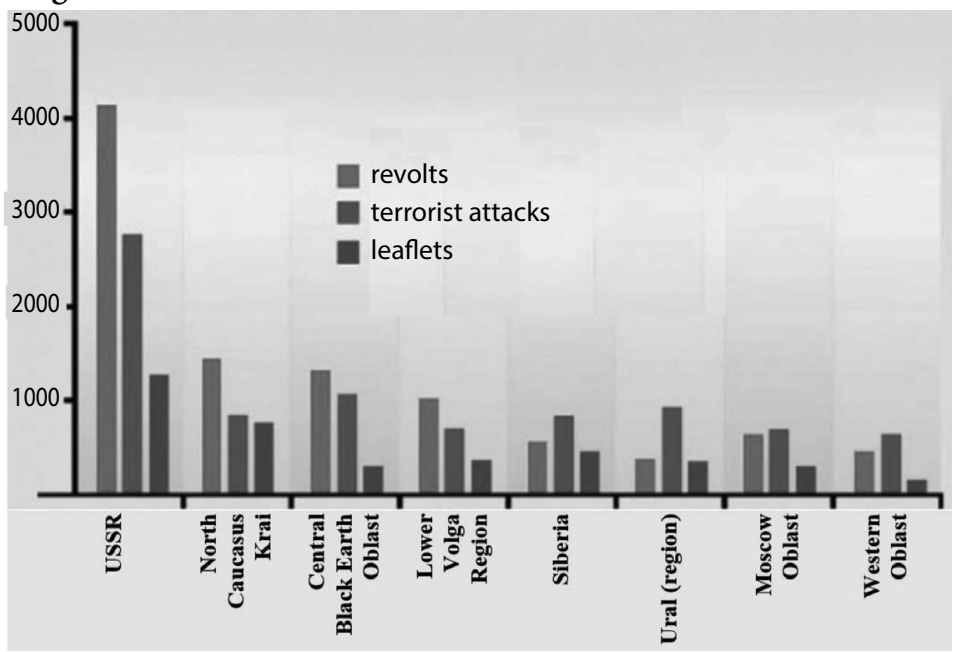

Source: [Tylishchak 2016].

Chart 2

The number of mass protest revolts members in the USSR in 1930

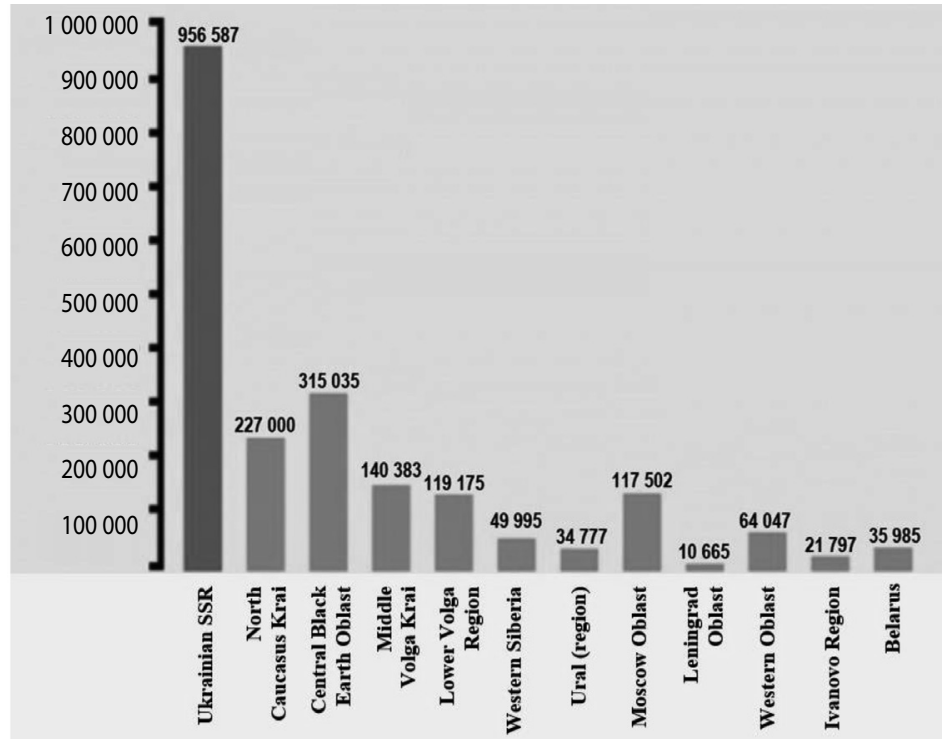

Source: [Tylishchak 2016]. 


\section{INFORMATION POLICY ON Holodomor IN THE USSR}

Information policy of the USSR strictly kept to the list of taboo topics [Luts 2015, 179]. The Holodomor topic of the 1932-1933s also belonged to this list. Such policy can be called an information blockage. Its technology has been outlined by Volodimir Viatrovich:

- censorship and disinformation,

- movement restrictions of people (which also means restrictions of spreading information),

- arrangement of "demonstration trips" to "sated Ukrainian villages",

- customized articles in mass media abroad,

- informational discredit of people who told about Holodomor abroad,

- criminal punishment for every reference to Holodomor,

- secrecy, liquidation and falsification of original resources (acts of social status, census data or any other archive records),

- insistence of the USSR on a "truncated" version of genocides concept in 1948 UN resolution (social groups were eliminated from the definition),

- manipulations based on researchers' mistakes (announcing mistakes as deliberate falsifications) [Dutsyk 2011].

Within the official informational space of the USSR there was no famine at all. Village councils had an order when registering death not to specify its reason. Later, in 1934 all books of ZAGS (governmental bodies registering the state of social status) on registering deaths in 1932-1933 were withdrawn and most of them were destroyed. When census of 1937 showed enormous population deficit the direction of Central Statistical Office was repressed and the census results were made secret. Prohibition of information about famine of the 1932-1933s in the USSR was in force until 1987 [Holodomor: henotsyd... 2008, 18; Kozhushko 2013].

\section{Parallel Reality in Soviet Nespapers OF 1932-1933}

First pages of soviet newspapers in the 30s of XXth century abounded in numerous publications elucidating success of the grain purchases with photos of festive overloaded bread carriages with flags and mottos like “... 
lets respond by endless ongoing bread carriages" [Screenshot 1], as well as propagandist articles which illustrated achievements on building socialism - opening of restaurants, department stores etc [Screenshot 2; Screenshot 3]. In contrast to "stability and prosperity" of soviet Ukraine the newspapers in details described famine and other troubles in other countries, particularly in Great Britain and the USA [Screenshot 4; Screenshot 5].

Screenshot 1

The Photo of Bread Carriage from Hola Pristan in Kherson region (newspaper "Proletarii" No.246 (2744), on 27.10.1932)

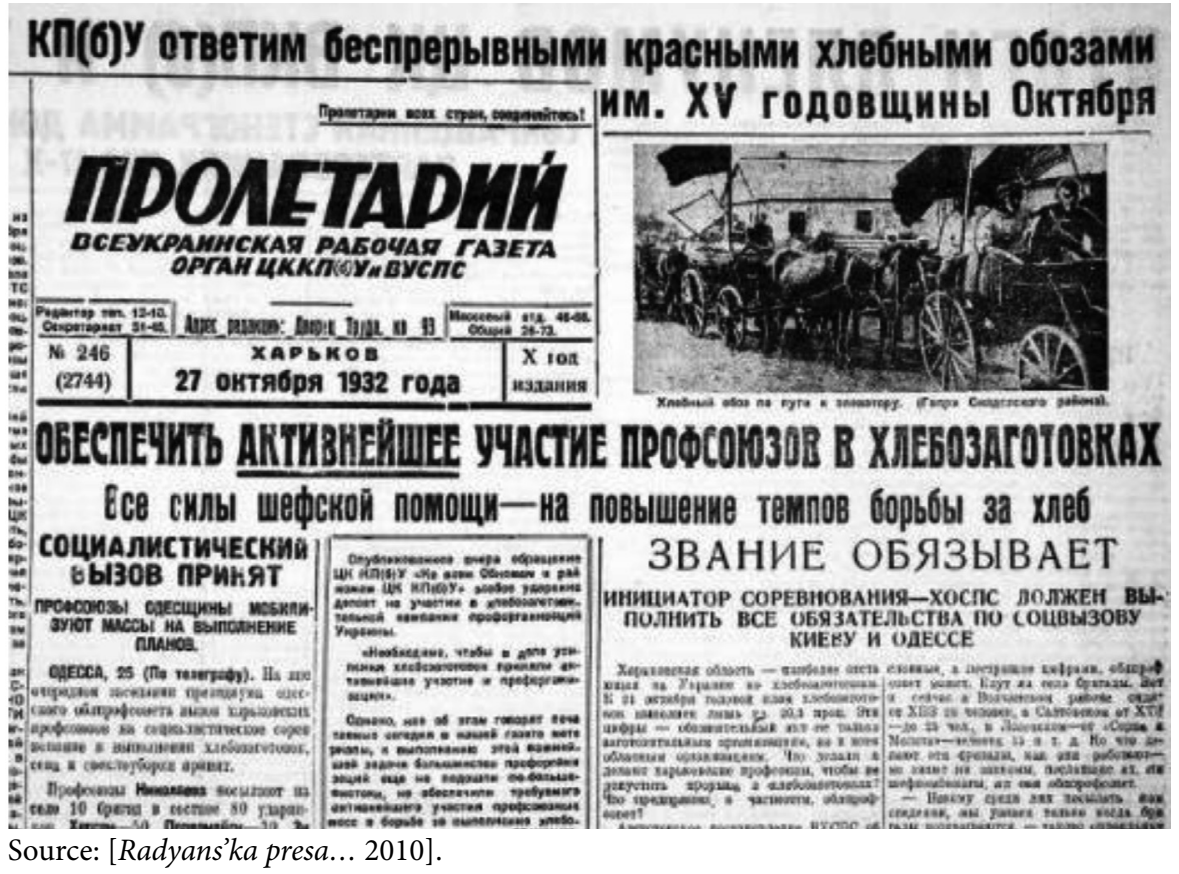


Screenshot 2

Advertisement on opening of a new big restaurant (newspaper "Proletarii")

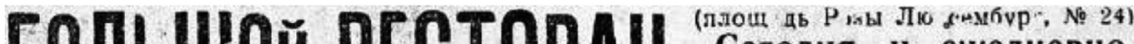

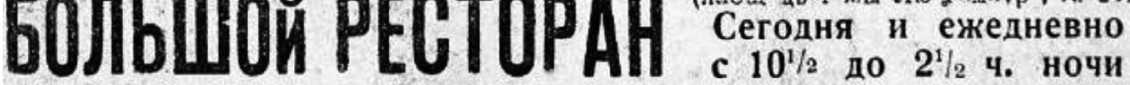 ЭСТРАДНЫЕ ВЫСТУППЕНИЯ пУиших АРТИстов

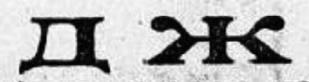 \\ юесторан открыт ежечневно до 4 час. ночи}

Source: [Radyans'ka presa... 2010].

Screenshot 3

Advertisement on opening of a new supermarket in Kharkiv (newspaper "Proletarii")

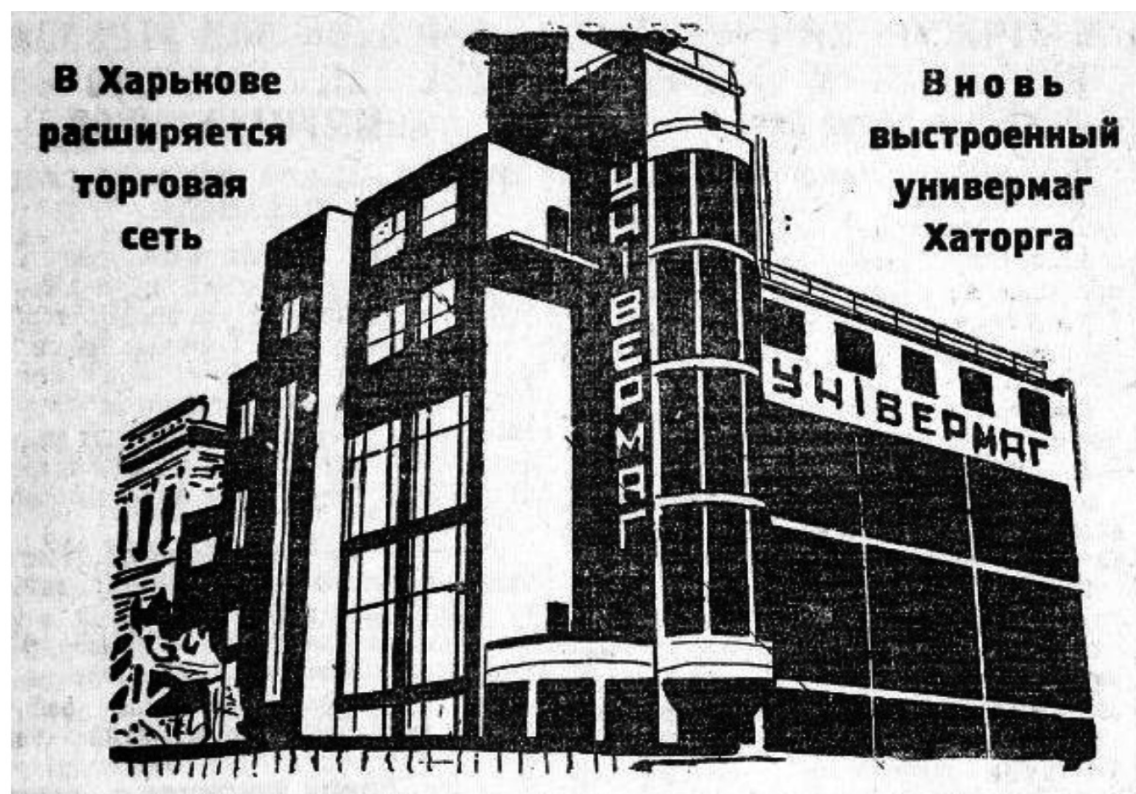

Source: [Radyans'ka presa... 2010]. 
Screenshot 4

Article "Troops of hungry campaign in London" with detailed description of jobless people (newspaper "Proletarii")

\section{ОТРЯДЫ ГОЛОДНОГО ПОЖОДА B JOHAOHE \\ КРОВАВЫЕ СТОЛКНОВЕНИЯ МЕЖДУ БЕЗРА- БОТНЫМИ И ПОЛИЦИЕй}

лондон, 28. Громаднал толпа лэндон- к Гайд парку. Тысячи полицейскт шо ских работих встречает в Гайд парье прововдали демонетрантов. прибваюицие отряды толодноло похода у ворот пәрка, кроме полицейстих, безраболных. Во всех стратегичеоких пун.ли сосредиточены отрлды добровольде птах западной части Јопдона рамполо- из буржуазии. В парсе состоялся х жены усиленшые наряды конноі и пе- тнит, в котором пршнали участие 10 шей полицин. Влереди отрялов безпабот тыс. человек. Ораторы прәнаносили рея ных ндут знаменосцы с қрасными знаме на 6 трпбунат.

нами, на жоторых изжбазен серп и мо Первое столюновение состоялось ия лот. у многих участников лачнаширекого парка, оволо Марбль Арч. Конная поли отряда перевязаны головы - резугьттат ожесточенных схваток с полицейскини по пути в Лондон. Каждуро коловну безработных сопровождают қонные II пешие полицеиские, а тагже долицейские авто мобили и мотодиклы.

лондон, 27. Сегопня пасте полудня, mесьь отрядов полоднопо похода безра-

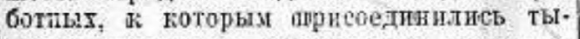
слчіп донданских безработиых, направилnсь в Ганд парж. Прежде, чем началось пествие, полиция обынивала демон-

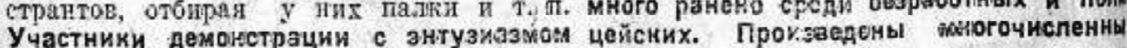
встречапись тысячами рабочих по пути аресты.

Source: [Radyans'ka presa... 2010]. 
Screenshot 5

Article with detailed description of jobless people demonstration under the title "Troops of hungry campaign in London" (newspaper "Proletarii")

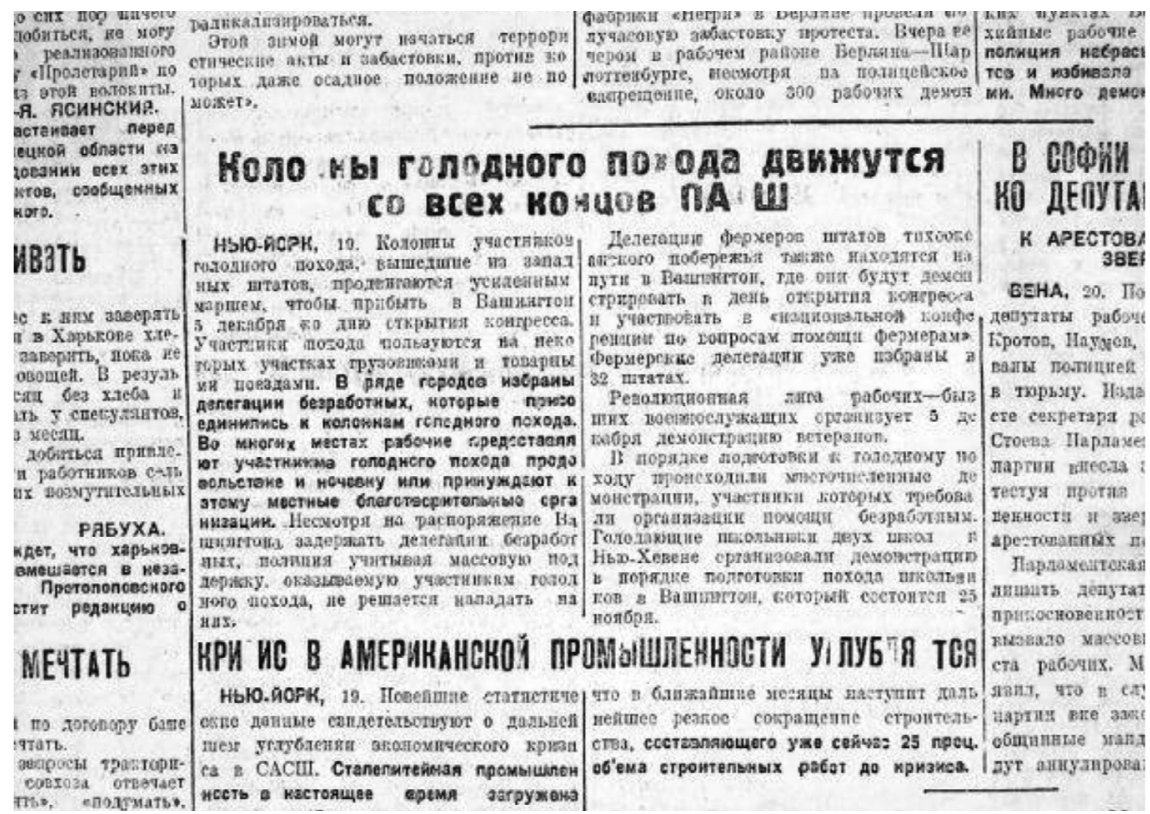

Source: [Radyans'ka presa... 2010].

\section{REPRESSIVE MEASURES}

The initiative to give collective farms property the legal status of governmental ownership (letter on July 20, 1932) belongs to J. Stalin personally, it was also him, who offered to introduce legal base for death penalty application for stealing of governmental property and eliminating of amnesty for the robbers, as "without draconian social measures it is impossible to establish new public discipline" [Stalin i Kaganovich: perepiska... 2001, 235]. So, special repressive measures, so called "black boards", were applied to the villages and regions, which resisted measures and policies of the soviet government either actively or passively. Punitive detachments were directed to such villages, food and industrial products trade were also forbidden there [Screenshot 6; Papakin 2013]. As for household owners in the villages, 
the "culprits of the sabotage", the highest punishment (death penalty) was applied "for counterrevolutionary activity against soviet government" [Holod 1932-1933 rokiv na Ukrayini: ochyma istorykiv...].

During the following years mentioning about famine in the USSR was a criminal offence and was punished by five-year imprisonment in the GULAG concentration camp, and accusation of the government was punished by death penalty [Conquest 2000,96$]$.

Screenshot 6

Advertisement about penal measures for the collective farms of the "black board" in newspaper "Under the Flag of Lenin" No.150, $1^{\text {st }}$ January, 1933

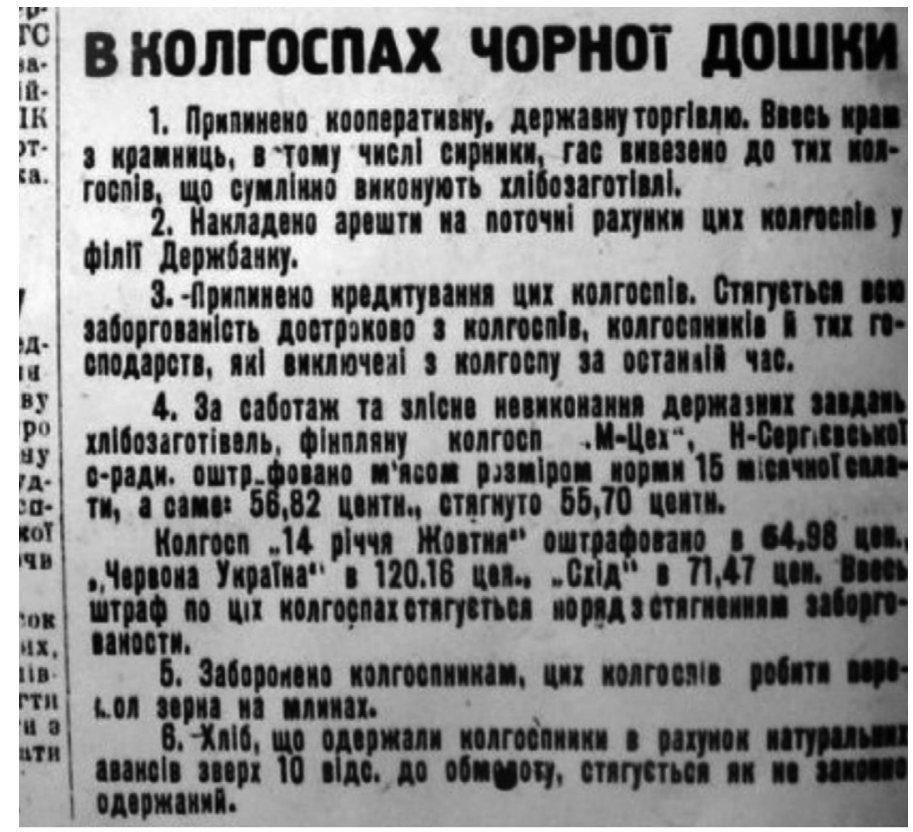

Source: [Papakin 2010].

\section{Holodomor Consequences}

Artificial famine was aimed at peasants [Holodomor 1932-1933 rokiv $v$ Ukrayini yak zlochyn henotsydu... 2013; The Foreign Office and the Famine... 1988]. And because it was peasants who were the most numerous part of Ukraine's population, Holodomor was actually genocides of Ukrainian 
people. The report of the Germany General Consulate in Kharkiv on $26^{\text {th }}$ January 1934 contains the following information: "This year Ukraine has been in a critical condition - there was a huge famine or, according to the government's definition, - the victory over social system in agriculture..." Holodomor: henotsyd... 2008, 6]. According to the Ptoukha Institute for Demography and Social Studies of the National Academy of Sciences of Ukraine [Infographic 1], during Holodomor of 1932-1933 over 3,9 million people died (122 people per every 1000 of inhabitants). The biggest mortality because of famine was in Kyiv, Poltava and Cherkassy regions, i.e. in the historical core of Ukrainian ethnos.

Infographic 1

Geography of Holodomor of 1932-1933

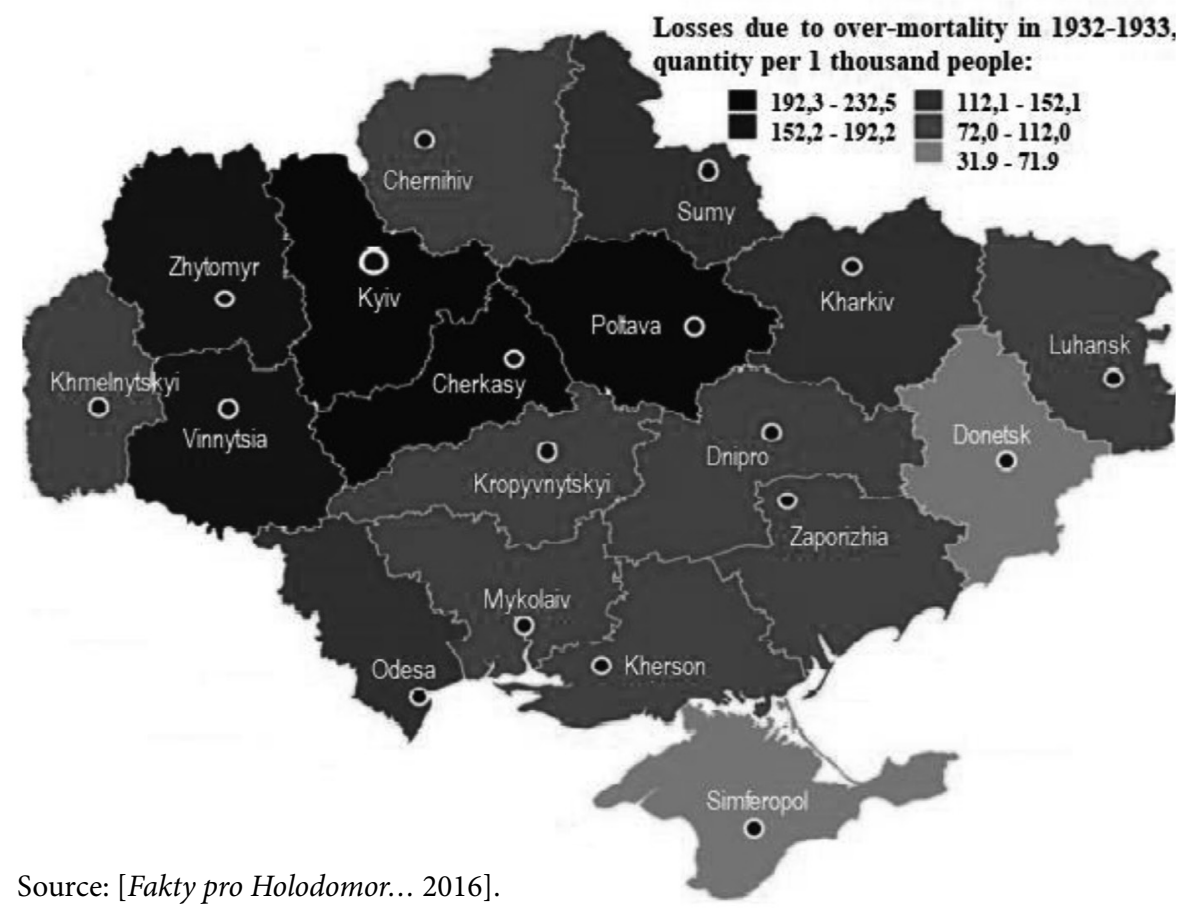

Peasants who survived didn't have any other way out except entering collective farms. None ever protested any more - the expression "no hunger 
by all means" became a life motto of the Ukrainian soviet people. Meanwhile, the documents related to famine became secret for many years. One of such documents is a record about death of 19-year old peasant Andrii Ostapenko, who died in Sumska region on $13^{\text {th }}$ May 1933. In the column 15 "death reason" it is written "the Ukrainian" [Screenshot 7].

\section{Screenshot 7}

The Act Record on $13^{\text {th }}$ May 1933 about death of Andrii Ostapenko

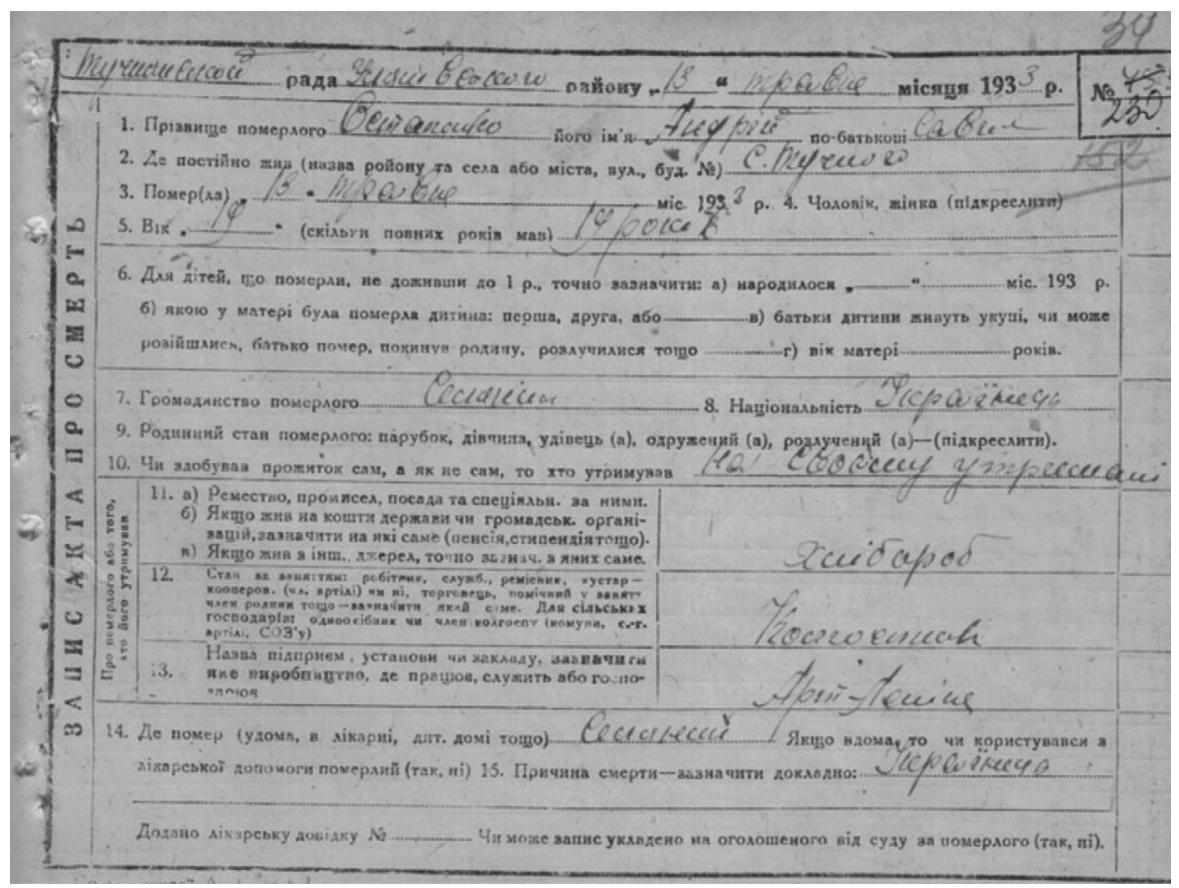

Source: [State Archive of Sumy region].

\section{Debunking OF THE MYTH}

In western press the first statement asserting that in the 1932-1933s Holodomor took place in Ukraine was made by journalist Gareth Richard Vaughan Jones [Gareth's website], who died due to secret circumstances, not having reached the age of 30 . 
The word "Holodomor" appeared in official statements of soviet politicians not earlier than in 1987. On the level of governmental appeals Holodomor started to be considered as genocide only in 1987 in Ukraine which was then already independent [Luts 2015, 183]. And only in 2006 Verkhovna Rada of Ukraine adopted the Law of Ukraine "On Holodomor of 1932-1933 in Ukraine”, suggested by Victor Yushchenko. The law recognizes public denial of Holodomor as the abuse of millions of Holodomor victim's memory, humiliation of Ukrainian people's dignity and is unlawful [Закон України “Про Голодомор 1932-1933...].

In 2009 the Security Service of Ukraine filed a case on the fact of genocide in Ukraine in the 1932-1933s. The case contains 253 volumes, it also has 1730 witnesses, mentions 735 settlements and 17 regions whose inhabitants were exterminated by famine, 857 places of mass graves had been found. 3 million 941 people who died right of the artificial famine were estimated. This criminal case resulted in made by Kyiv Court of Appeal adoption of the Resolution on the criminal case filed on the genocide commitment fact in Ukraine in the 1932-1933s. The main culprits according to the case are sate and party leaders of the USSR and Ukrainian SSR as well as J. Stalin, V. Molotov, L. Kaganovich, P. Postishev, S. Kosior, V. Chubar, M. Khatayevich who in the 1932-1933s deliberately organized the genocide for the certain part of the Ukrainian national group, aiming at suppression of the national liberation movement in Ukraine and preventing establishment as well as affirmation of the Ukrainian independent state [Postanova Apelyatsiynoho sudu... 2010].

UNESCO [Remembrance of victims of the Great Famine... 2007, 72-73], OSCE Parliamentary Assembly [Resolution of OSCE... 2008], European Parliament [European Parliament resolution... 2008] adopted documents on commemoration of Holodomor victims. Vatican as well as legislative organs of dozens of other countries recognized Holodomor as genocide against Ukrainian people, and parliaments of many countries adopted documents on commemoration of Holodomor victims. Decisions recognizing Holodomor as genocide have been approved on regional and municipal levels in many countries of the world [Kozhushko 2013; Holodomor: Ukrainian genocide..., 21-22; Recognition of Holodomor...]. 
States UN members made joint statement on $70^{\text {th }}$ anniversary [Joint statement on the seventieth anniversary... 2003] and announced declaration on $75^{\text {th }}$ Holodomor anniversary [Declaration on the seventy-fifth anniversary... 2008].

On April 28, 2010 Parliamentary Assembly of the Council of Europe adopted resolution "On Commemoration of Great Famine (Holodomor) Victims in Former USSR" [Resolution of OSCE... 2010], and therefore recognized Holodomor a crime against humanity; it also appealed to the states to open archives and encouraged historians to research the problem independently in order to reveal complete, objective and non-politicized truth about this tragedy.

Today they provide possibility to see many documents in open access, particularly with such electronic resources as:

- Consolidated Registry of archive documents of Holodomor Electronic Archive [Henotsyd ukrayins'koho narodu...],

- Branch State Archive of the Security Service of Ukraine [Holodomor 1932-1933 rokiv v Ukrayini: khronika podiy],

- Unified Register of Holodomor Victims [Unified register of Holodomor Victims...],

- "Memory about Holodomor of the 1932-1933s" rubric on the Ukrainian Institute of National Memory website [Pam'yat' pro Holodomor 1932-1933...],

- website of the National Museum "Holodomor Victims Memorial" [Holodomor victims Memorial...],

- Figure Atlas of Holodomor [The Great Famine in Ukraine...],

- "Holodomor" rubric of the specialized history oriented website "Historical truth" [Holodomor 1932-1933: Internet-proekt] etc.

\section{Conclusions}

Technology of Soviet myth creation about Holodomor in the 1932-1933s as a result of crop failure demonstrates wide spectrum of alternative reality creation means (mythologization), was exploited during the whole history of soviet government, - destruction of documents and evidence, intimidation and physical destruction of witnesses, blockage of access to the sources of true information, alternative "truth" creation and its spreading in mass media. 
Russian information space has been territorial localization of the myth existence. Government of the USSR must be considered a mythmaker. The aim of creating and spreading of the myth was to form and enroot in mass consciousness "ideologically correct" interpretation of history, which was supposed to hide criminal offences and disguise them under the ecological myth.

It is impossible to define the exact number of the dead due to certain reasons: 1) liquidation of 1937 population census data (census executors were shot) 2) incomplete death fixation, 3) fixation of other death reasons instead of death due to fame. According to the Ptoukha Institute for Demography and Social Studies of the National Academy of Sciences of Ukraine, during Holodomor of the 1932-1933s over 3,9 million people died. The Holodomor consequences were considerable ruination of the Ukrainian village as culture carrier, ruination of marriage potential etc. However, psychological compulsion of Ukrainian population and its subordination to soviet government was the main psychological consequence of Holodomor, which was disguised by mythologization techniques.

Mythologization of Holodomor in Ukraine of the 1932-1933s has been only one among many other examples of alternative soviet reality creation, which are worth special scientific researches.

\section{Legal regulatory acts}

Postanova Apelyatsiynoho sudu mista Kyiva za kryminal'noyu spravoyu, porushenoyu za faktom vchynennya henotsydu v Ukrayini v 1932-1933 rokakh, vid 13.01.2010. [Court of Appeal in Kyiv City Resolution for a criminal case filed on the fact of committing genocide in Ukraine in 1932-1933. Resolution on $13^{\text {th }}$ January 2010.]. Official website of the Ukrainian Institute of national Memory. Retrieved from: http:// www.memory.gov.ua/publication/postanova-apelyatsiinogo-sudu-mista-kieva-zakriminalnoyu-spravoyu-porushenoyu-za-faktom (in Ukrainian).

The Law of Ukraine No 376-V on November 28, 2006: On the Holodomor of 19321933 in Ukraine. Date of entry into force: December 1, 2006. Retrieved from: http://zakon5.rada.gov.ua/laws/anot/en/376-16 (in Ukrainian). 


\section{References}

Conquest, R. (2000). Reflections on a Ravaged Century. ISBN 0393048187.

Dolot, M. (1985). Execution by Hunger: The Hidden Holocaust. New York: W.W. Norton \& Company, 231 p. ISBN 0-393-01886-5. http://history.org.ua/Liber UA/978-0-393-30416-9/978-0-393-30416-9.pdf

The Foreign Office and the Famine: British documents on Ukraine and the Great Famine of 1932-1933. (1988). Edited by Marco Carynnyk, Lubomyr Y. Luciuk and Bohdan S. Kordan. With a foreword by Michael R. Marrus. Kingston, Ontario; Vestal, New York: Limestone Press. 493 p. ISBN 0-919642-31-4. Retrieved from: http://diasporiana.org.ua/wp-content/uploads/books/13544/file.pdf

Holodomor 1932-1933 rokiv $v$ Ukrayini yak zlochyn henotsydu zhidno $z$ mizhnarodnym pravom. [Holodomor of the 1932-1933s in Ukraine as a Genocide Crime according to the International Law]. (2013). Scentific Editor: V. Vasylenko, M. Antonovych. Kyiv: Publishing House "Kyiv-Mohyla Academy", 360 p. ISBN 9789665186106. Retrieved from: http://history.org.ua/Liber UA/978-966-518-610-6/978-966-518-610-6.pdf (in Ukrainian).

Holodomor: henotsyd ukrayins'koho narodu 1932-1933. [Holodomor: Genocide of Ukrainian People in the 1932-1933s]. (2008). Publication ordered by the Institute of National Memory. Kyiv: Publishing House named after Olena Teliga, 25 p. Retrieved from: http://www.memory.gov.ua/sites/default/files/buklet_holodomor_ukr.pdf (in Ukrainian).

State Archive of Sumy region. Fund P.7720, Inventory 1, Case 458, Sheet 34. Retrieved from: https://higher-caps.livejournal.com/470456.html (in Ukrainian).

Luts, Yu. (2015). Informatsiyna polityka $\mathrm{v}$ konteksti trahediyi Holodomoru 1932-1933 rr. todi i sohodni: chy pomitni zminy? [Information Policy in the context of Holodomor Tragedy in the 1932-1933s then and now: are the chances noticeable?]. Ukraïna: narracje, języki, historie. Pod redakcja Marcina Gaczkowskiego. Wrocław: Stowarzyszenie Badaczy Popkultury i Edukacji Popkulturiwej „Trickstier”, s. 179-191. ISBN 978-83-64863-02-8. Retrieved from: https://www.academia.edu/28664607/Ukra\%D1\%97na_ narracje_j\%C4\%99zyki_historie (in Ukrainian).

Papakin, H. (2013). "Chorna doshka": antyselyans'ki represiyi (1932-1933). ["The Black Board": anti-peasant repressions (1932-1933)]. Resp.ed. H. Boriak. Kyiv: Institute of History of Ukraine at the National Academy of Science of Ukraine, 422 p. ISBN 9789660270237. Retrieved from: http://history.org.ua/Liber UA/978-966-02-7023-7/978-966-02-7023-7.pdf (in Ukrainian). 
Stalin i Kaganovich: perepiska 1931-1936 gg. [Stalin and Kaganovich: correspondence of the 1931-1936s]. (2001). Compiler O.V. Khlevniuk, R.U. Devis, L.P. Kosheleva, E.A. Ris, L.A. Rogovaia. Moscow: "Russian Political Encyclopedia"(ROSSPEN), 798 p. Retrieved from: ftp://ftp.zachem.org/\%C8\%F1\%F2\%EE\%F0\%E8\%F F/\%D1\%F2\%E0\%EB\%E8\%ED\%20-\%20\%EA\%ED\%E8\%E3\%E8\%20\%FD \%EF\%EE\%F5\%E8/\%D1\%E1\%EE\%F0\%ED\%E8\%EA\%E8/\%D1\%F2\%E0\% EB\%E $8 \%$ ED \% 20\%E8\% 20\%CA\%E0\%E3\%E0\%ED\%EE\%E2\%E 8\%F7.\%20 \%CF\%E5\%F0\%E5\%EF\%E8\%F1\%EA\%E0.\%201931\%20-\%201936\%20\%E3\%E3. pdf (in Russian).

Stariv, S. (2006). Kazn' golodom. [Execution through Famine]. Kyiv: Prosvita, 272 p. ISBN 9668547845. http://krotov.info/lib_sec/05_d/ol/ot.htm (in Russian).

\section{Internet resources}

Declaration on the seventy-fifth anniversary of the Holodomor of 1932-1933 in Ukraine, A/63/613, General Assembly of United Nations, 16 December 2008, Annex to the letter dated 16 December 2008 from the Permanent Representative of Ukraine to the United Nations addressed to the Secretary-General. Retrieved from: https://documents-dds-ny.un.org/doc/UNDOC/GEN/N08/656/68/PDF/ N0865668.pdf?OpenElement

European Parliament resolution P6_TA(2008)0523 of 23 October 2008 on the commemoration of the Holodomor, the Ukraine artificial famine (1932-1933). Retrieved from: http://www.europarl.europa.eu/sides/getDoc.do?type=TA\&reference=P6-TA2008-0523\&format=XML\&language $=\mathrm{EN}$

Gareth's website. Retrieved from: http://www.garethjones.org/index.htm

Holodomor victims Memorial. Website of National Museum. Retrieved from: http:// memorialholodomor.org.ua/eng/

Holodomor: Ukrainian genocide in the early 1930s. Kyiv: Ukrainian Institute of National Memory. 26 p. Retrieved from: http://un.mfa.gov.ua/mediafiles/files/ holodomor-booklet.pdf

Joint statement on the seventieth anniversary of the Great Famine of 1932-1933 in Ukraine (Holodomor), A/C.3/58/9, General Assembly of United Nations, 7 November 2003. Annex to the letter dated 7 November 2003 from the Permanent Representative of Ukraine to the United Nations addressed to the SecretaryGeneral. Retrieved from: https://documents-dds-ny.un.org/doc/UNDOC/GEN/ N03/604/02/PDF/N0360402.pdf?OpenElement 
Maestro. (2010). Henotsyd ukrayins'koho narodu 1932-1933. [Genocide of Ukrainian People in the 1932-1933s]. National Truth. Publication 13.01.2010. http://narodna.pravda.com.ua/history/4b4d6e4ac0964/ (in Ukrainian).

Recognition of Holodomor as genocide in the world. Website of National Museum "Holodomor victims Memorial". Retrieved from: http://memorialholodomor.org. ua/eng/holodomor/genocide/act/

Remembrance of victims of the Great Famine (Holodomor) in Ukraine. Resolution 15 adopted by the General Conference at its 34th session, on 1 November 2007. Records of the General Conference 34th session Paris, 16 October - 2 November 2007. Volume 1: Resolutions. United Nations Educational, Scientific and Cultural Organization (UNESCO), Paris, 2007, 182 p. Retrieved from: http://unesdoc. unesco.org/images/0015/001560/156046e.pdf

Resolution of OSCE Parliamentary Assembly 1723: Commemorating the victims of the Great Famine (Holodomor) in the former USSR. Text adopted by the Assembly on 28 April 2010 (15th Sitting). Retrieved from: http://assembly.coe.int/nw/xml/ XRef/Xref-XML2HTML-en.asp?fileid=17845\&lang=en

Resolution of OSCE Parliamentary Assembly: On the Holodomor of 1932-1933 in Ukraine. Text adopted by the Assembly on 03 July 2008 (17th Sitting). Retrieved from: http://www.europarl.europa.eu/RegData/courrier_officiel/arrivee/2008/EPPE_LTA(2008)007956_EN.pdf

The Great Famine in Ukraine - Holodomor. Ukrainian Institute of Harvard University. Retrieved from: http://harvard-cga.maps.arcgis.com/apps/webappviewer/index.ht ml?id=d9d046abd7cd40a287ef3222b7665cf3

Henotsyd ukrayins'koho narodu: Holodomor 1932-1933 rr. [Genocide of Ukrainian People: Holodomor of the 1932-1933s.]. Special section of the official web-portal of the State Committee of Archives of Ukraine: Electronic Archive of Holodomor. Retrieved from: http://www.archives.gov.ua/Sections/Famine/ (in Ukrainian).

Holitsyna, N. (2017). Holodomor buv navmysno sprychynenyy Stalinym - Epplbaum pro svoyu knyzhku "Chervonyy holod. Viyna Stalina z Ukrayinoyu". [Holodomor was caused by Stalin deliberately - Appleboum about her book "The Red famine. Stalin War with Ukraine"]. Publication 25.09.2017. Retrieved from: https://www. radiosvoboda.org/a/28756326.html (in Ukrainian).

Holod 1932-1933 rokiv na Ukrayini: ochyma istorykiv, movoyu dokumentiv. [Famine of the 1932-1933s in Ukraine: by the eyes of historians, in the language of documents]. Governmental Archive Service of Ukraine. Retrieved from: http://www.archives. gov.ua/Sections/Famine/Publicat/Fam-Pyrig-1932.php\#Top (in Ukrainian). 
Holodomor 1932-1933 rokiv v Ukrayini: khronika podiy. [Holodomor of the 1932-1933s in Ukraine: Events Chronicle.]. Official website of the Security Service of Ukraine. Retrieved from: https://ssu.gov.ua/ua/pages/209 (in Ukrainian).

Holodomor 1932-1933: Internet-proekt. [Holodomor of the 1932-1933s: Internetproject]. Historical Truth. Retrieved from: http://www.istpravda.com.ua/themes/ holodomor/ (in Ukrainian).

Dutsyk, D. (2011). Vidtsenzurovanyy Holodomor. [Censored Holodomor]. MediaSapiens. Publication 03.12.2011. Retrieved from: http://www.osvita. mediasapiens.ua/ethics/manipulation/vidtsenzurovaniy_golodomor/ (in Ukrainian).

Unified register of Holodomor Victims. Retrieved from: http://victimsholodomor. org.ua/

Kozhushko, O.M. (2013). Ukrayina vidznachaye 80-u richnytsyu Holodomoru. [Ukraine celebrates the $80^{\text {th }}$ anniversary of Holodomor]. Official website of the Ministry of Foreign Affairs of Ukraine. Publication 22.11.2013. Retrieved from: http://mfa.gov.ua/ua/press-center/interviews-and-articles/1798-ukrajinavidznachaje-80-u-richnicyu-golodomoru (in Ukrainian).

Pam'yat' pro Holodomor 1932-1933. [Memory about Holodomor of the 1932-1933s]. Official website of the Ukrainian Institute of National Memory. Retrieved from: http://www.memory.gov.ua/page/pamyat-pro-golodomor-1932-1933 (in Ukrainian).

Papakin, H. (2010). "Chorni doshky" Holodomoru - ekonomichnyy metod znyshchennya hromadyan URSR (spysok). ["Black Boards" of Holodomor - Economical method of the USSR citizens' destruction (list)]. Historical Truth. Publication 27.11.2010. Retrieved from: http://www.istpravda.com.ua/ research/2010/11/27/6591/ (in Ukrainian).

Pres-reliz do Dnya pamyati zhertv Holodomoriv. [Press release on The Day of Holodomos' Victims Commemoration]. (2015). Ptoukha Institute for Demography and Social Studies of the National Academy of Sciences of Ukraine. Retrieved from: http://www.idss.org.ua/arhiv/2015_26_11_press_release.pdf (in Ukrainian).

Radyans'ka presa 1932-1933: Holodni bunty na Zakhodi, novi restorany u Kharkovi. [Soviet Press of the 1932-1933s: Hunger Outbreaks in the West, New Restaurants in Kharkiv]. (2010). Historical Truth. Retrieved from: http://www.istpravda.com.ua/ artefacts/2010/11/7/3319/\#0 (in Ukrainian).

Tylishchak, V. (2016). Ponad 5000 masovykh vystupiv: yak ukrayins'ke selo chynylo 
sprotyv kolektyvizatsiyi. [Over 5000 Mass Revolts: How Ukrainian Village resisted Collectivization]. Historical Truth. Publication 23.11.2016. Retrieved from: (29.04.2018): http://www.istpravda.com.ua/articles/2016/11/23/149335/ (in Ukrainian).

Fakty pro Holodomor v Ukrayini 1932-33 rr. [Facts about Holodomor in Ukraine of 1932-1933]. (2016). Infographic. Publication 23.11.2016. Web-platform UA Modna. Retrieved from: http://www.uamodna.com/articles/fakty-pro-golodomr-vukrayini-1932-33-rr-infografika/ (in Ukrainian). 